Vol. 11, No. 38, January, 2016, 1-17

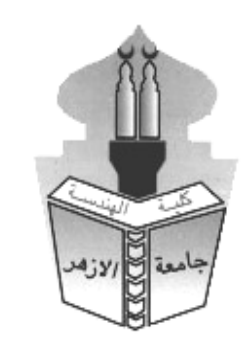

\title{
AN EXPERIMENTAL INVESTIGATION OF AN INNOVATIVE COUPLING TECHNIQUE OF CONCRETE SHEAR WALLS
}

\author{
Dalia F. Arafa ${ }^{1}$, Hamed M. Salem ${ }^{2}$, and Mohamed E. Issa ${ }^{2}$ \\ ${ }^{1}$ Concrete Structures Research Institute, Housing and Building Research Center, Egypt \\ ${ }^{2}$ Concrete Structures, Faculty of Engineering, Cairo University, Cairo, Egypt

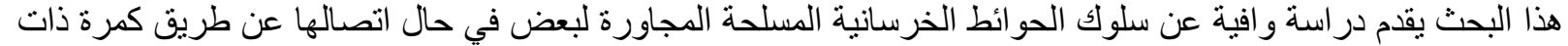

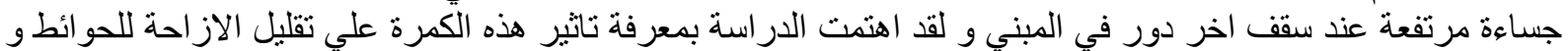

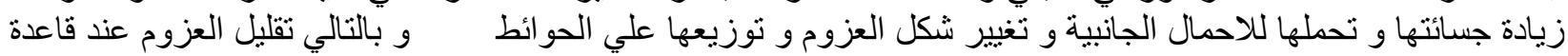

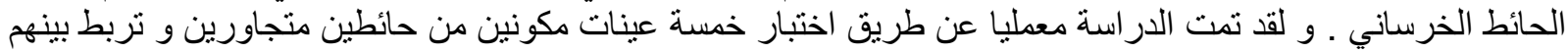 \\ كمرة ذات جساءات مختلفة عن طريق زيادة العمق في كل عينة و تعريض هذه العينات لحمل جانبي بالاضافة الي حمل راسي راسي \\ موزع علي كل حائط.
}

ABSTRACT

This research work experimentally investigates an innovative shear walls coupling for enhancement of seismic performance of reinforced concrete structures. The new proposed technique links plane, relatively distant, shear walls with a top roof beam constituting framedshear walls. An experimental investigation is carried out for five 1/5 scale models. Each model consists of two $100 \mathrm{~mm}$ x $600 \mathrm{~mm}$ shear walls with $1800 \mathrm{~mm}$ height, connected by a $1200 \mathrm{~mm}$ long beam at their top with variable depth as a main examined parameter. The depth of top beam ranged from $200 \mathrm{~mm}$ to $600 \mathrm{~mm}$. As a complementary to the scope of study, a numerical analysis of the test specimens was carried out using The Applied Element Method (AEM). Both the experimental and analytical results showed reasonable enhancement in strength of coupled shear walls using the proposed technique.

\section{Keywords: Shear Walls; Stiffening Beam, depth, Experimental Analysis, ELS Software}

\section{INTRODUCTION}

The control of top drift and flexure in main lateral load resisting system in structures under lateral loads has become the main concern in the structural seismic design. The outrigger-braced system is regarded as one of the most effective ways of increasing structural stiffness and has been widely used. This was examined by several researchers. Fouad ${ }^{[1]}$ investigated the feasibility of using a top outrigger to stiffen a pair of coupled shear walls. The structure resisting lateral loads studied consisted of two-in plane walls connected by beams located at each floor level. The external columns located at the same walls plane contributed to the stiffness of the shear walls by placing a stiffening outrigger at the top of the walls. The outrigger and the peripheral columns resisted the walls rotation and reduced both moments and lateral drift. Ghan and Kuang ${ }^{[2]}$ presented an analytical method for investigating the beneficial effect of a stiffening beam on coupled shear walls internal forces and top deflection. The main variable was the location of the outrigger over the structural height. The application of a stiffening beam into coupled shear walls reduced the maximum shear force in the lintel beams and the base moment in the walls and the 
top drift of the structure. J.R.Wu and Q.S.Li ${ }^{[3]}$ presented a detailed analysis on the influence of variable outrigger locations and structural stiffness when a multi-level outrigger-braced tall building structure is subjected to uniformly distributed forces or triangularly distributed loads on the top drift, base moment in the core and the fundamental vibration period. The author concluded, that when the structure is subjected to horizontal triangular loads the optimum location of outrigger ranges between $4-5 \%$ compared to horizontal uniform loads. One of the most important deductions in this study, that the optimum location of outriggers is as near as possible to the foundation to reduce the base moment in the core. Bayati,Mahdikhani and Rahaei 4] presented the results of an investigation on drift reduction in uniform belted structures with rigid outriggers, through the analysis of a 80 story steel framed office. The proposed system consists of bracing at the walls of the 15 meters square core and three sets of outriggers located along the building height. Many benefits were offered by using the outrigger concept by the example demonstrated by the researchers such as, there are no trusses in the space between the core and the exterior columns. All exterior columns participate in resisting the overturning moments and the difficult connection between the truss and the core is eliminated. Wdowicki and Wdowicka ${ }^{[5]}$ investigated the non-planar asymmetric shear wall structures with stiffening deep beams located at various levels of coupled shear walls in tall buildings. The continuous connection method approach was used as a design tool for variable cross section coupled shear walls. In practice it was founded that the lintel beams on walls have limited depths, therefore it is necessary to insert deep beams somewhere along the height on the buildings. Numerical examples were presented to demonstrate the versatility and accuracy of the proposed technique. Kamath, Divya and Rao ${ }^{[6]}$ numerically inspected the behavior of different alternatives of 3D models with central core and a deep stiff beam connecting the central core to the most exterior columns. The height of the building has a major role in using these stiff beams, because when the height of the building increases, the core loses its adequate stiffness to keep the wind drift down to accepted limits. Two systems were analyzed through a dynamic analysis and compared, one with an outrigger and the second without. The model considered for analysis was a threedimensional 40 story building with $7 \mathrm{~m} \times 8 \mathrm{~m}$ central shear wall. It was concluded by the authors that the lateral displacement reduced about $37 \%$ by providing the outrigger the top and reduced up to $61 \%$ by providing outriggers at mid-height. The magnitude of the reduction in bending moments at base is of the order $95 \%$ by providing outriggers at mid-height of the core. The restraining movement of the columns to the outrigger system is the cause of this high reduction.

\section{RESEARCH SIGNIFICANCE}

In multistory structures, lateral loads caused by wind and earthquake actions are often resisted by a system of shear walls located usually at sides of the building or in the form of a core which houses staircases or elevator shafts. The current study aims to experimentally investigate the structural efficiency of coupling in-plane relatively distant shear walls by a stiff beam at their top. For this purpose, five $1 / 5$ scaled specimens were subjected to monotonic loading. Behavior is evaluated in terms of the redistribution of bending moments in the shear walls, the lateral load capacity increase of the coupled walls, and the reduction of the top drift. 


\section{EXPERIMENTAL PROGRAM}

\subsection{Test specimens}

Five framed shear wall specimens were casted. Each specimen consists of two typical shear walls having $100 \mathrm{~mm} \times 600 \mathrm{~mm}$ cross section and a total height of $1800 \mathrm{~mm}$. Each specimen had a reinforced concrete footing of a cross section of $400 \mathrm{~mm}$ x $400 \mathrm{~mm}$ and a total length of 3400 $\mathrm{mm}$ as shown in Fig. (1). All specimens had the same longitudinal wall reinforcement ratio of $1.16 \%(14 \varnothing 8)$ and same lateral reinforcement of $6 \varnothing 8 \mathrm{~mm}$ per meter of wall height as shown in Fig. (1). The top connecting beam of each specimen has different depth and reinforcement as shown in Fig. (1) and Table (1). The coupling beam was reinforced with top and bottom reinforcement of $2 \varnothing 8 \mathrm{~mm}, 3 \varnothing 8 \mathrm{~mm}, 4 \varnothing 8 \mathrm{~mm}, \quad 5 \varnothing 8 \mathrm{~mm}$ and $6 \varnothing 8 \mathrm{~mm}$ for specimens SWB10x20, SWB10x30, SWB10x40, SWB10x50, and SWB10x60, respectively. The depth of the connecting beam was the main investigated parameter. The reinforced concrete base were fixed to the laboratory rigid floor through two steel anchors with diameter $50 \mathrm{~mm}$. Tests were conducted at the Housing and Building Research Center HBRC Laboratory.

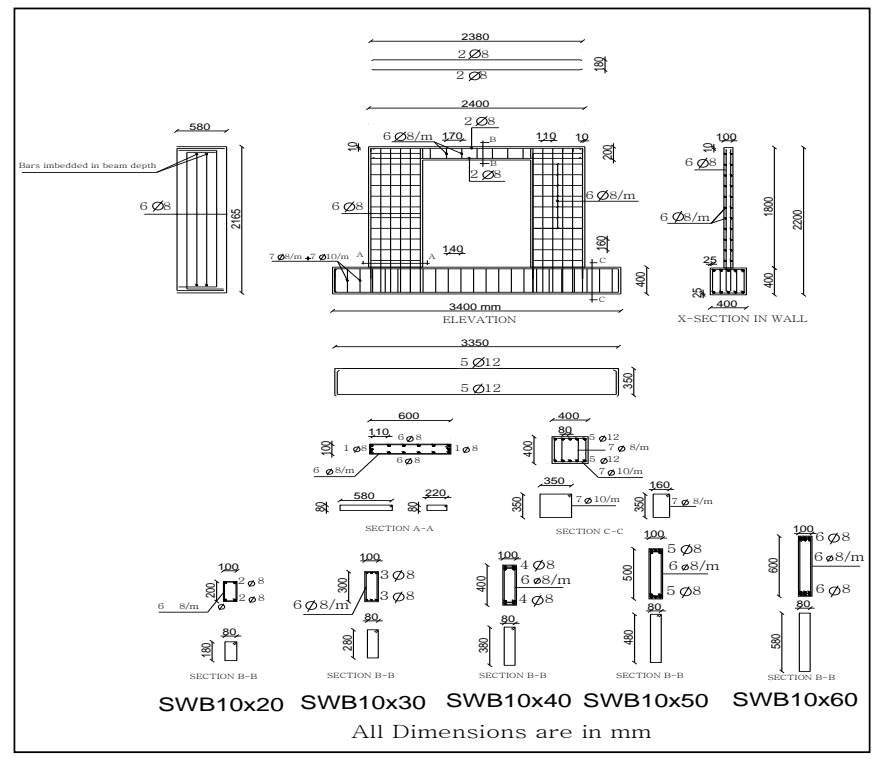

Fig. (1) Specimens Dimensions and Reinforcement

Table (1): Test Parameters and Concrete Dimensions

\begin{tabular}{|c|c|c|c|}
\hline \multirow{2}{*}{ Specimen ID } & Top Beam dimensions BxH $(\mathbf{m m})$ & \multicolumn{2}{|c|}{ Top Beam Reinforcement } \\
\cline { 3 - 4 } & & TOP & BOTTOM \\
\hline SWB10x20 & $100 X 200$ & $2 \emptyset 8$ & $2 \emptyset 8$ \\
\hline SWB10x30 & $100 X 300$ & $3 \emptyset 8$ & $3 \emptyset 8$ \\
\hline SWB10x40 & $100 X 400$ & $4 \emptyset 80$ & $4 \emptyset 8$ \\
\hline SWB10x50 & $100 X 500$ & $5 \emptyset 8$ & $5 \emptyset 8$ \\
\hline SWB10x60 & $100 X 600$ & $6 \emptyset 8$ & $6 \emptyset 8$ \\
\hline
\end{tabular}

\subsection{Material Properties}

\subsubsection{Reinforcing Bars}

Mild Steel bars with grade 280/450 with diameter of $\varnothing 8 \mathrm{~mm}$ was used for Shear walls and top beam main vertical reinforcement and stirrups. Deformed High strength steel with grade 400/600 with diameter $\varnothing 10 \mathrm{~mm}$ and $\varnothing 12 \mathrm{~mm}$ was used for footing reinforcement. The tensile tests were conducted on reinforcing bar test pieces $(300 \mathrm{~mm})$ length in a Universal Tension Machine for each bar diameter. Test results are presented in Table (2). 
AN EXPERIMENTAL INVESTIGATION OF AN INNOVATIVE COUPLING TECHNIQUE OF CONCRETE SHEAR WALLS

Table (2): Steel Properties

\begin{tabular}{|c|c|c|c|c|c|}
\hline $\begin{array}{c}\text { Bar Diameter } \\
(\mathbf{m m})\end{array}$ & Grade & $\begin{array}{c}\text { Unit } \\
\text { Weight } \\
\mathbf{K g} / \mathbf{m}\end{array}$ & $\begin{array}{c}\text { Yield } \\
\text { Stress } \\
\mathbf{M P a}\end{array}$ & $\begin{array}{c}\text { Ultimate } \\
\text { Stress } \\
\mathbf{M P a}\end{array}$ & $\begin{array}{c}\text { Elongation } \\
\%\end{array}$ \\
\hline 8 & $280 / 450$ & 0.184 & 305.00 & 465.00 & 52.50 \\
\hline 10 & $400 / 600$ & 0.267 & 590.00 & 744.00 & 19.10 \\
\hline
\end{tabular}

\subsubsection{Cement}

Ordinary Portland Cement (CEM1) was used during the study. The specific weight of the cement was chosen 3.15. The used cement complies with the Egyptian Standard Specifications ESS 4756-1-2006.

\subsubsection{Aggregates}

Coarse aggregate was used in concrete mixture with nominal size $5 \mathrm{~mm}$, while natural sand was used as fine aggregate in all concrete mixes. The coarse and fine aggregates had a specific weight of 2.60 and 2.50 , respectively.

\subsubsection{Admixtures}

Sikament $163 \mathrm{M}$ was added to the concrete mix to improve its workability.

\subsection{Preparation of Test Specimens}

The concrete mix proportions for the five specimens are given by weight in Table (3). The mixes were designed for a compressive strength of $30 \mathrm{MPa}$ at 28 days. Fresh concrete was vibrated by a $25 \mathrm{~mm}$ diameter internal poker vibrator until satisfactory compaction was achieved. After casting, specimens were covered with wet clothes. All specimens were stripped from their molds after 24 hours and then stored in a curing water tub. Standard concrete cubes of $15 \times 15 \times 15 \mathrm{~cm}$ dimensions were sampled from the each specimen patch to determine the concrete strength at 7 days, 28 days and the test day. Nine cubes were poured from every specimen. Three cubes were tested 7 days after casting, three other cubes 28 days after casting, and the remaining three cubes were tested at the test day. Table (4) shows the 28 days and the test day compressive strength obtained from compression cube tests.

Table (3) Concrete Mix Design for each specimen

\begin{tabular}{|l|c|c|c|c|c|}
\hline Constituents & $\begin{array}{c}\text { Cement } \\
(\mathbf{k g})\end{array}$ & $\begin{array}{c}\text { Fine Aggregate } \\
(\mathbf{k g})\end{array}$ & $\begin{array}{c}\text { Coarse } \\
\text { Aggregate (kg) }\end{array}$ & $\begin{array}{c}\text { Water } \\
\text { (lit) }\end{array}$ & $\begin{array}{c}\text { Workability } \\
\text { additives } \\
\text { (lit) }\end{array}$ \\
\hline SWB10X20 & 35.425 & 80.138 & 120.206 & 18.775 & 850 \\
\hline SWB10X30 & 35.750 & 80.873 & 121.30 & 19.00 & 850 \\
\hline SWB10X40 & 35.750 & 80.873 & 121.30 & 19.00 & 850 \\
\hline SWB10X50 & 36.725 & 83.078 & 124.618 & 19.50 & 880 \\
\hline SWB10X60 & 37.375 & 84.549 & 126.823 & 19.80 & 890 \\
\hline
\end{tabular}

\begin{tabular}{|c|c|c|}
\hline \multicolumn{2}{|c|}{ Table (4) Compression Strength Results of the Specimens } \\
\hline \multirow{2}{*}{ Specimen } & \multicolumn{2}{|c|}{ Compressive Strength $f c u\left(N / \mathbf{m m}^{2}\right)$} \\
\cline { 2 - 3 } & 28 Days & Test Date \\
\hline SWB10X20 & 33.33 & 39.33 \\
\hline SWB10X30 & 35.55 & 40.00 \\
\hline SWB10X40 & 33.18 & 40.15 \\
\hline SWB10X50 & 31.55 & 41.77 \\
\hline SWB10X60 & 35.55 & 41.60 \\
\hline
\end{tabular}


The specimens were casted horizontally in wooden forms as shown in Fig. (2).

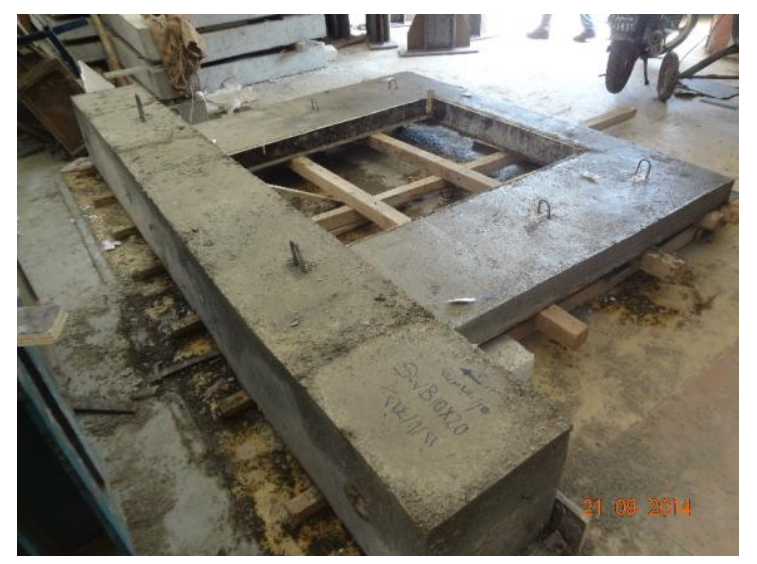

Fig. (2) Specimen SWB10X20 after casting

\subsection{Test setup and instrumentations}

The test setup details and the loads applied are shown in detail in Fig. (3). Each specimen was fixed to the laboratory ground by two anchoring bolts at two fixed points. Torque was applied to the anchoring bolts to ensure complete fixation to the ground before testing. A hydraulic Jack of $1000 \mathrm{KN}$ capacity was used to apply a vertical load of $220 \mathrm{KN}$ at the top of the shear walls through a rigid steel Beam of $200 \mathrm{~mm}$ depth resting on several rods placed on the top of the walls. The steel rods were used to distribute the axial load on the walls. A hydraulic jack of 1000 $\mathrm{KN}$ capacity was used to apply a horizontal load racking load at the top of the left wall with a special head to allow for pushing of the specimen. The head provided a lateral guide to the specimen to prevent it from torsional or side deformations as shown in Fig. (4).

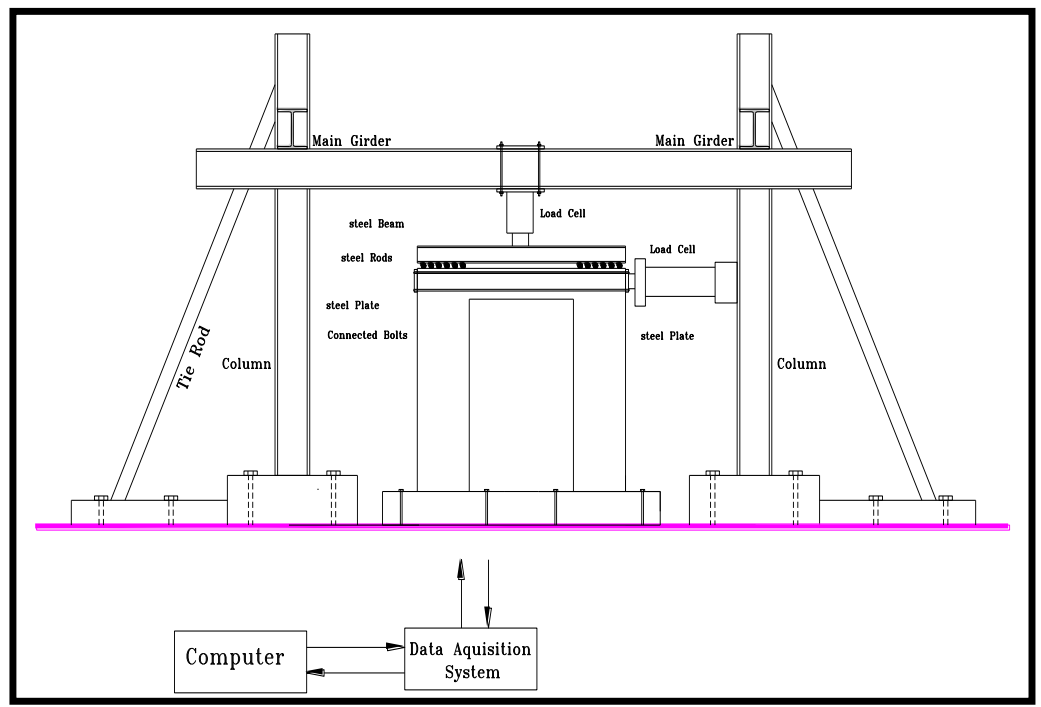

Fig. (3) Loading Setup 


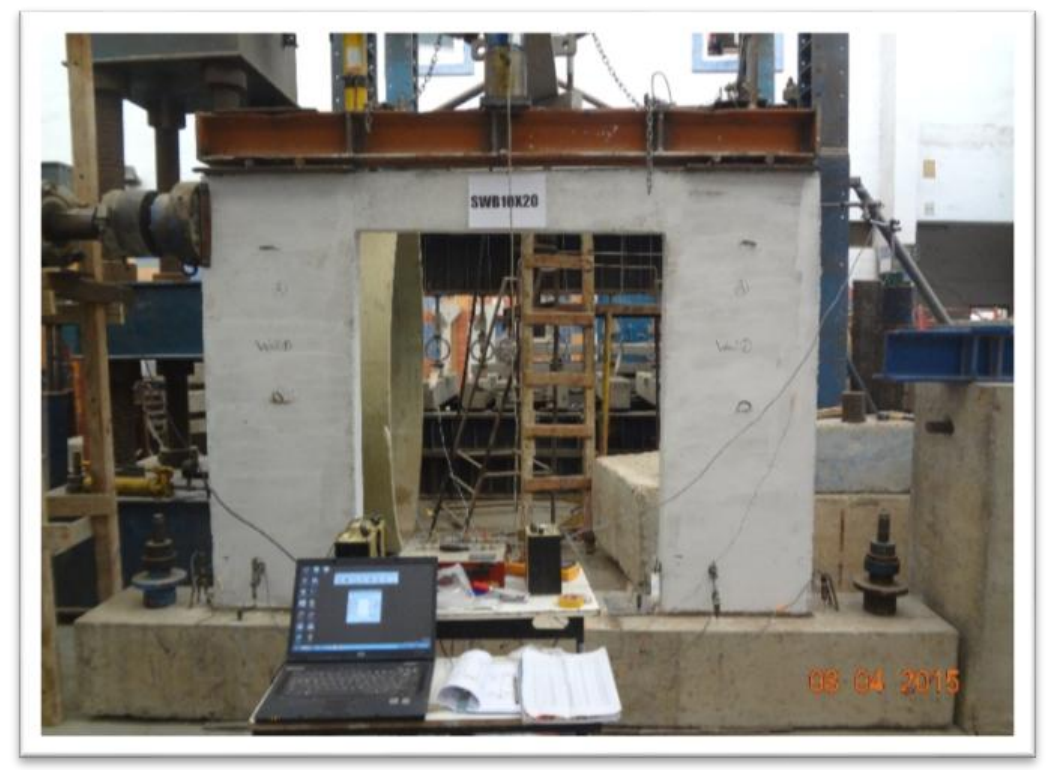

Fig. (4) Specimen SWB10X20 Test Setup and Measurements

Linear Variable Differential Transformer (LVDT) and strain gauges were used to measure deformations and strains in the test specimens. The positions of the LVDTs and the strain gauges are shown in Fig. (5) .Six steel strain gauges were bonded to reinforcement at tension sides and two concrete strain gauges were bonded to concrete at compression fibers. All measurements were controlled by the structural laboratory data acquisition system in HBRC. The axial load was applied first followed by the racking load till specimen failure. Before loading zero readings of strains and LVDTs were recorded.

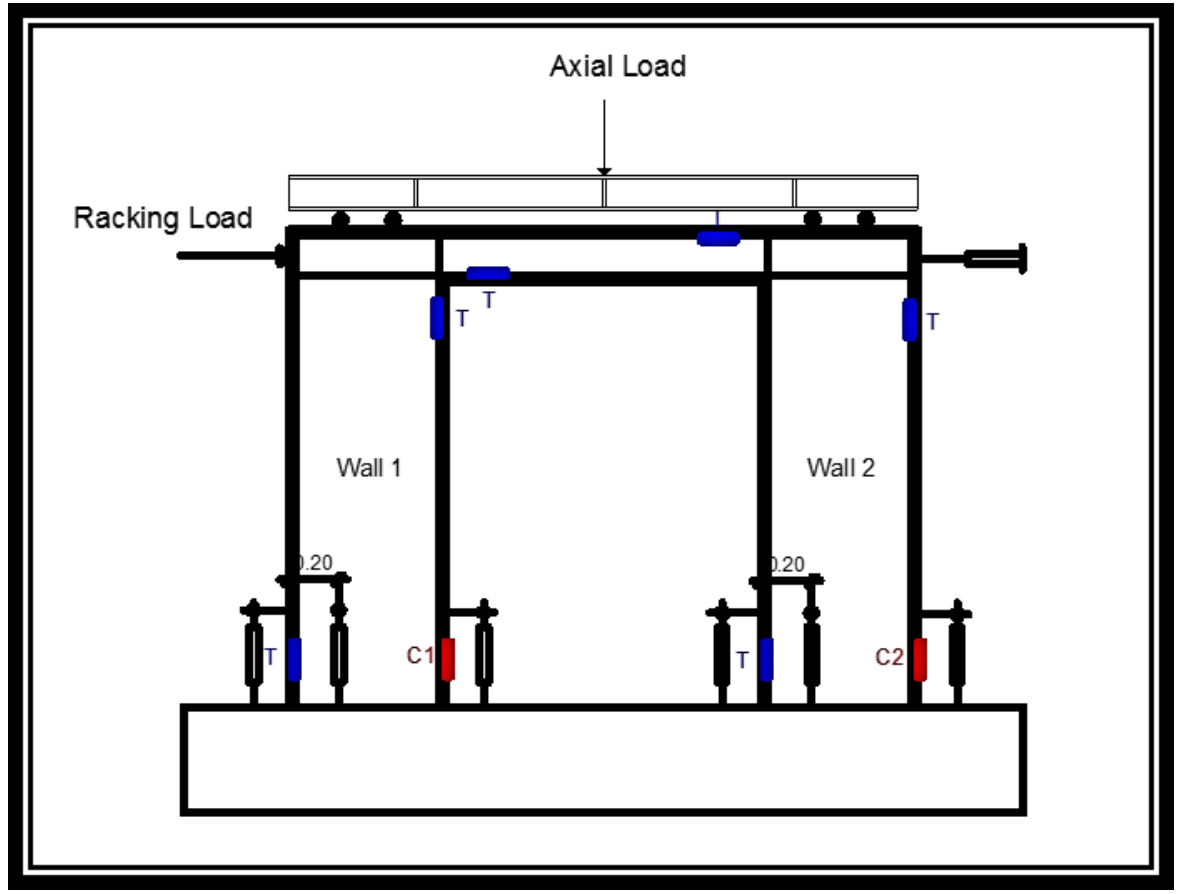

Fig. (5) Specimens Measurements 


\section{EXPERIMENTAL RESULTS AND DISCUSSION}

The relation between the applied horizontal load and the top drift for all specimens is shown in Fig. (6). It is clear that the increase in top beam depth had a great influence on increasing the lateral load capacity of the frame. The failure loads were $178.80 \mathrm{KN}, 220.40 \mathrm{KN}, 257.30 \mathrm{KN}$, $305.20 \mathrm{KN}$ and $332.60 \mathrm{KN}$, respectively. It is obvious from the previous relation the great effect of connecting two shear walls by a stiff beam at top in increasing the lateral load capacity as presented in Fig. (7). Compared to the reference specimen (SWB10X20), the stiffest specimen (SWB10X60) showed an $86.07 \%$ gain in lateral load capacity.

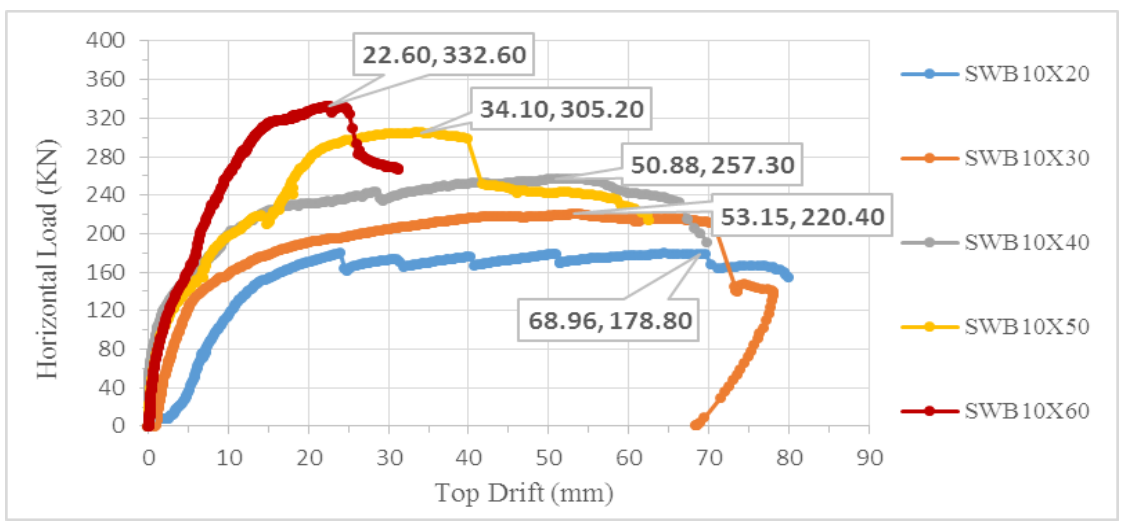

Fig. (6) Lateral Load - Deflection Curves for all Specimens

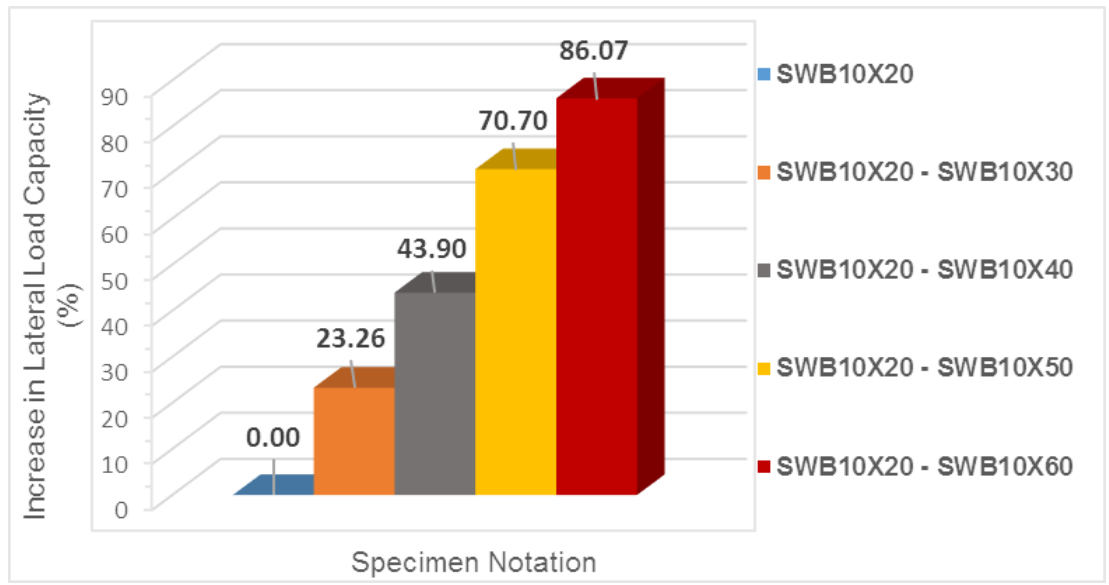

Fig. (7) Efficiency of System in increasing Lateral Load Capacity

The suggested system had also an influence on the top drift of the frame. The decrease in the top drift reached $67.09 \%$ when beam depth equaled $600 \mathrm{~mm}$ (SWB10X60) compared to a weak connecting beam (SWB10X20) as illustrated in Fig. (8). 


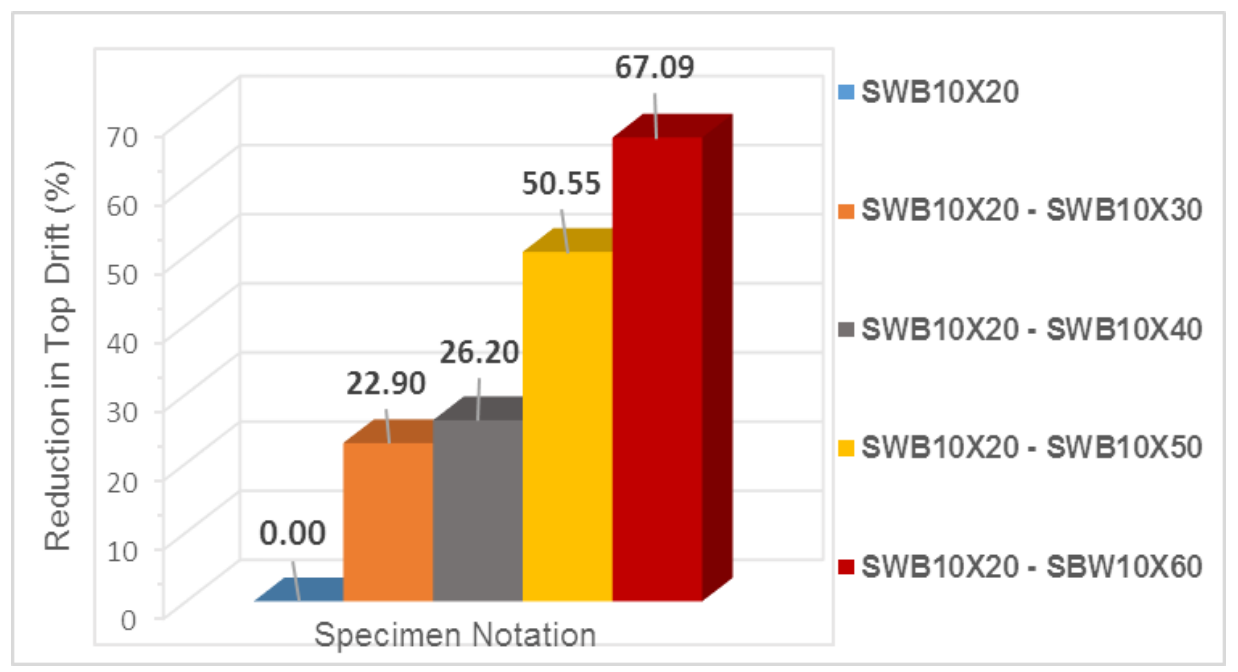

Fig. (8) Efficiency of System in decreasing the Top Drift

The energy dissipation capacity per unit volume was calculated for each specimen as the area under the lateral load-top drift curve as shown in Table (5).

Table (5): Area under $P$ - $\Delta$ Curve

\begin{tabular}{|c|c|}
\hline Specimen & Energy dissipated $(\mathbf{k N . m m )}$ \\
\hline SWB10X20 & $\mathbf{3 8 2 7 9 . 3 0}$ \\
\hline SWB10X30 & $\mathbf{6 1 6 6 6 . 7 0}$ \\
\hline SWB10X40 & $\mathbf{6 3 2 4 5 . 6 0}$ \\
\hline SWB10X50 & $\mathbf{6 5 7 4 5 . 3 0}$ \\
\hline SWB10X60 & $\mathbf{8 7 0 5 6 . 2 0}$ \\
\hline
\end{tabular}

For all specimens, Cracks initiated at the tension side of the walls, at their bottom, and tension side of the top beam. i.e., at their connections with the walls. Cracks then propagated towards the compression side and reinforcement yielded constituting four plastic Hinges in each specimen as shown in Figure (9). Eventually, failure ended up in most specimen by the crushing of concrete at base of wall (2), except the two specimens with the stiffest top beam, SWB10X50 and SWB10X60, which exhibited a shear failure in wall (2).

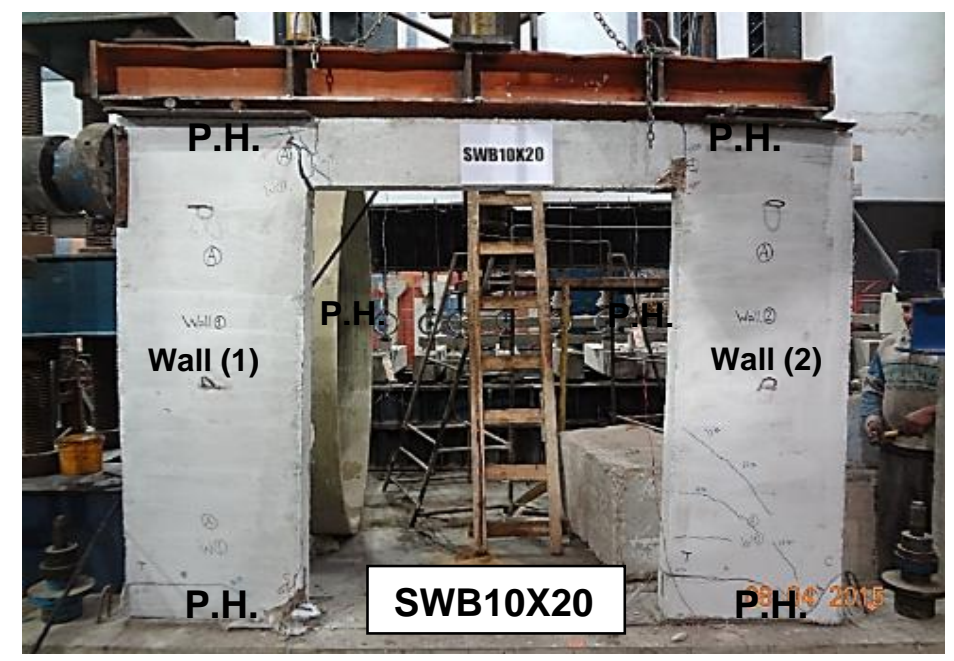



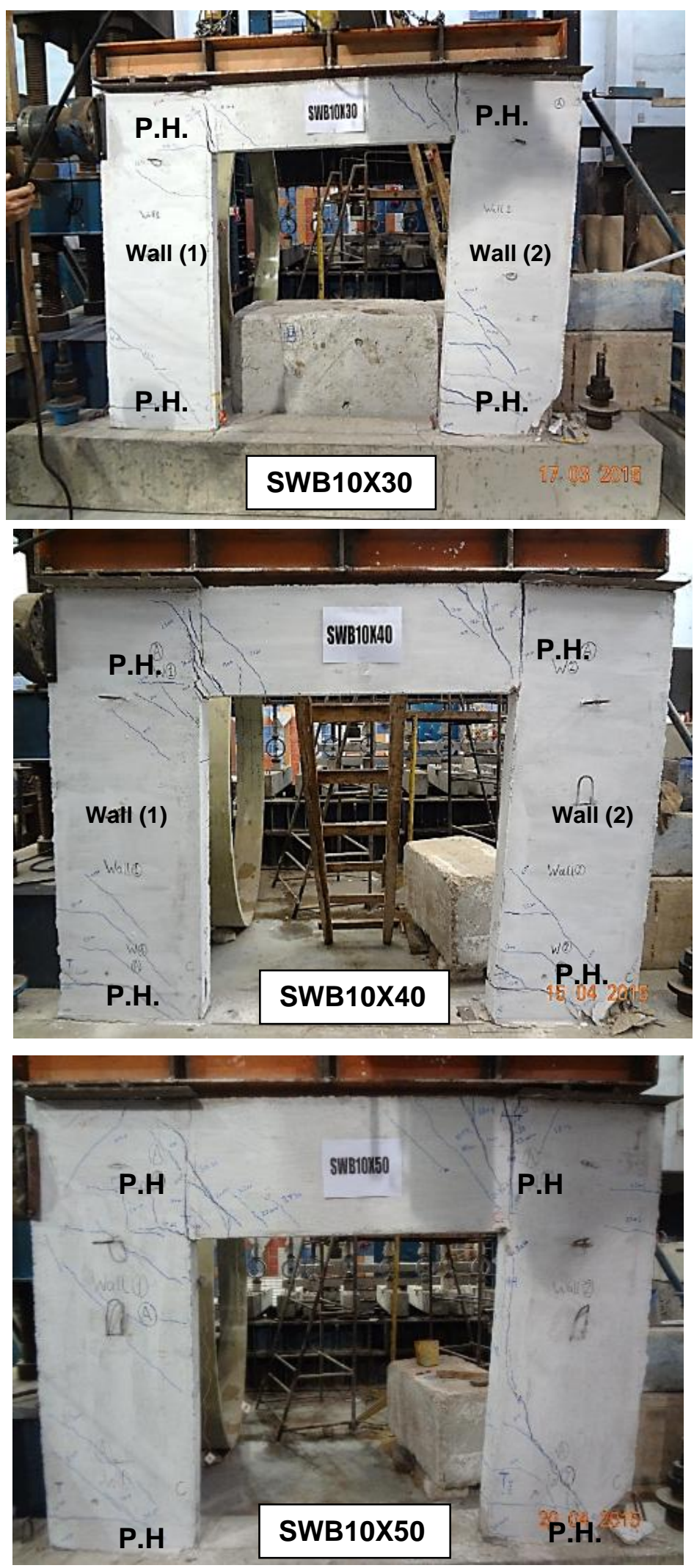


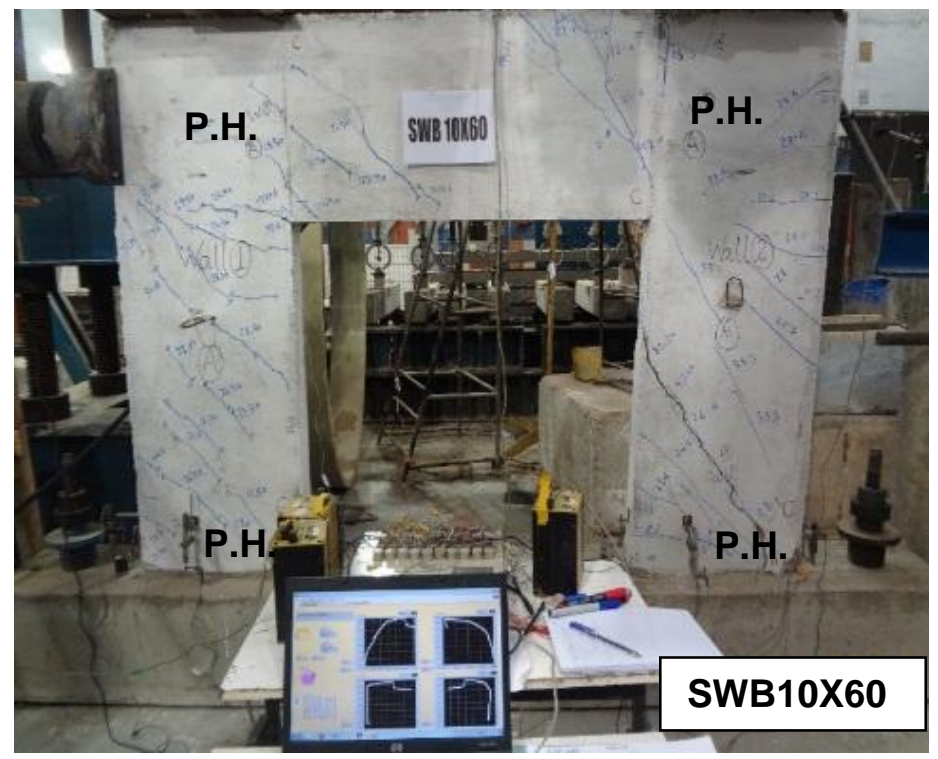

Fig. (9) Failure Patterns for all Specimens

\section{ANALYSIS OF THE TEST SPECIMENS}

A nonlinear analysis was carried out for the specimens using the Applied element Method (AEM) [7-21]. The AEM is a new method, which is capable of predicting to a high degree of accuracy the continuum and discrete behavior of structures during a collapse situation. The Applied Element Method (AEM) was proven to be the method that can track the structural collapse behavior passing through all stages of the application of loads: elastic stage, crack initiation and propagation in tension-weak materials, reinforcement yielding, element separation, element collision (contact), and collision with the ground and with adjacent structures. Literature has shown that the Applied Element Method (AEM) theory gives good estimations for large displacements and deformations of structures undergoing collapse. The reason for using the AEM is that in the analysis of the full scale structures with the proposed coupling method, the performance of the structure is investigated till its collapse which is most suitable to be carried out by the AEM. AEM is a modeling method adopting the concept of discrete cracking. As shown in Fig.(10), the structure in the AEM is modeled as an assembly of elements connected together along their surfaces through a set of normal and shear springs. They can represent both concrete and steel reinforcing bars. The analysis was carried out using the Extreme Loading of Structure (ELS) software ${ }^{[22]}$, which is based on the Applied Element Method (AEM).

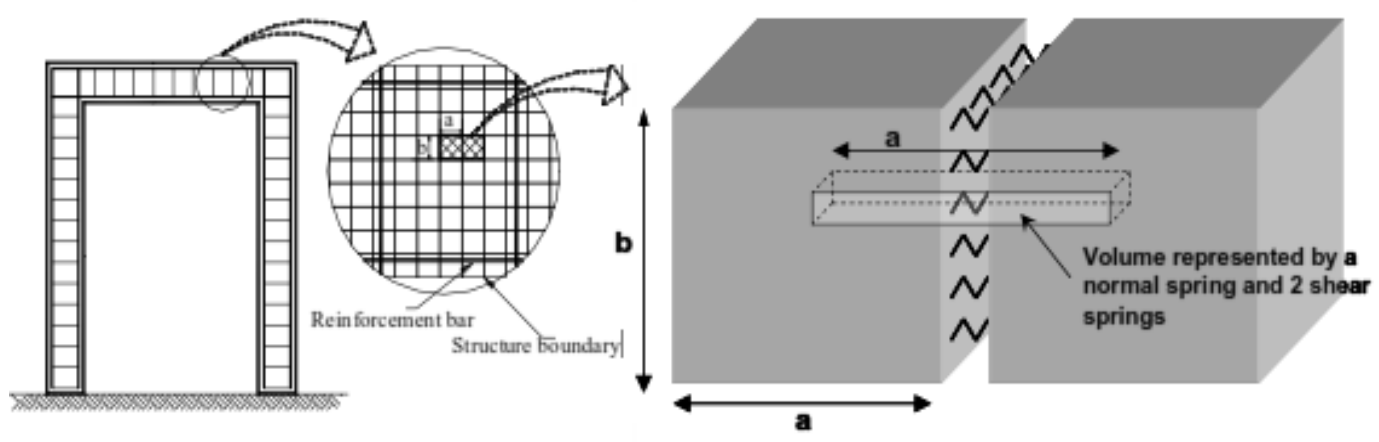

Fig. (10) Spring Distribution and Area of Influence of each pair of Springs 
Before and after cracking as for modeling of concrete under compression, the elasto-plastic and fracture model of Maekawa ${ }^{[23]}$ as shown in Fig.(11-a) is adopted. For concrete springs subjected to tension, spring stiffness is assumed as the initial stiffness until reaching the cracking point. After cracking, stiffness of springs subjected to tension is dropped to be zero. For concrete springs, the relationship between shear stress and shear strain is assumed to remain linear till the cracking of concrete. Then, the shear stresses drop down as shown in Fig. (10-b). The level of drop of shear stresses depends on the aggregate interlock and friction at the crack surface. For reinforcement springs, the model presented by Ristic et al. ${ }^{[24]}$ is used and it is shown in Fig. (11c). The tangent stiffness of reinforcement is calculated based on the strain from the reinforcement spring, loading status (either loading or unloading) and the previous history of steel spring which controls the Bauschinger's effect. For more details about material models used, refer to Tagel-Din and Meguro ${ }^{[25]}$.

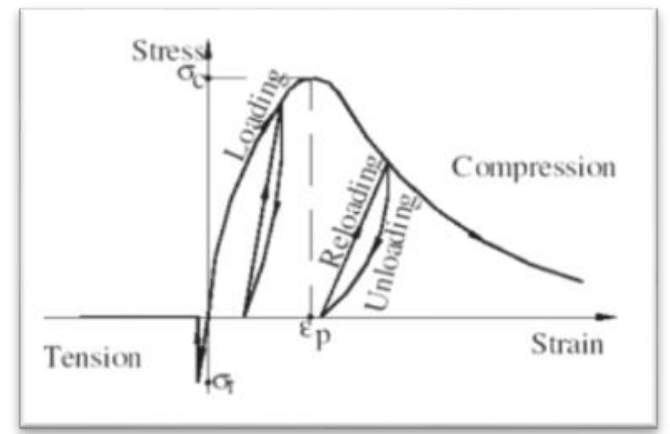

(a) concrete under axial stresses

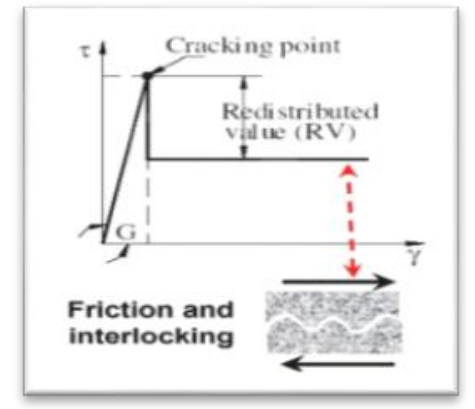

(b) concrete under shear stresses

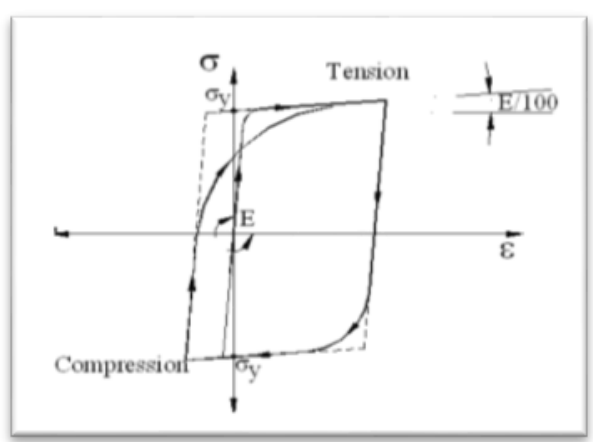

(c) Reinforcement under axial stresses

Fig. (11) Constitutive Models tor Concrete and Keintorcement used in ELS

Figure (12) shows the frame modeled in ELS. The loading scenario with the axial loads on each wall, the lateral load and the boundary conditions are illustrated. The boundary conditions are modeled as two fixed points in the footing as carried out in the experiments. A displacement control scenario was used to add a concentrated lateral load to the shear wall frame.

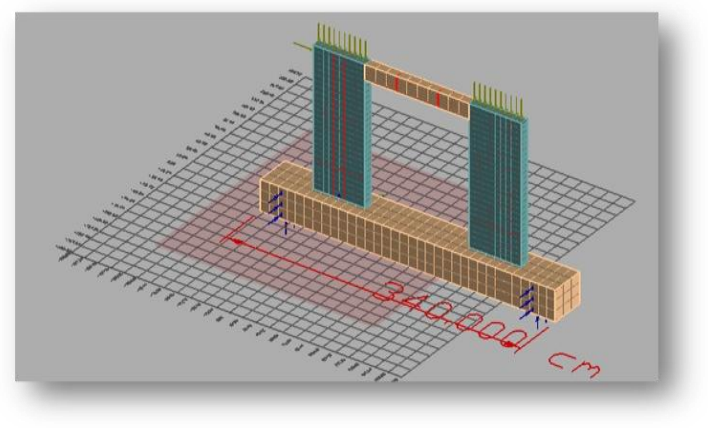

Fig. (12): ELS 1/5 Scaled Model 
The numerical results are compared to the experimental ones concerning the Lateral Load - Top Drift relation and the moment distribution in the shear walls. Figure (13) through Figure (17) present the lateral load-drift relations for the analysis compared to the experimental results for the test specimens. Reasonable agreement between the numerical results and the experimental ones with differences ranging from $12.00 \%$ to $24.00 \%$ in capacity estimation and from $41.00 \%$ to $68.00 \%$ in estimation of drift at peak load. It is evident that an early peak with less drift is estimated by the ELS, which means less ductility than reality is calculated. Figure (18) through Figure (22) shows the principal strain contours calculated by the ELS Software ${ }^{\text {22] }}$ after the peak Load of each specimen to highlight the effect of the top beam stiffness on the concentration of stresses regions .The principal strain contours shows a good agreement with the observed experimental cracking pattern. A summarized comparison between experimental and numerical results are shown in Table (5).

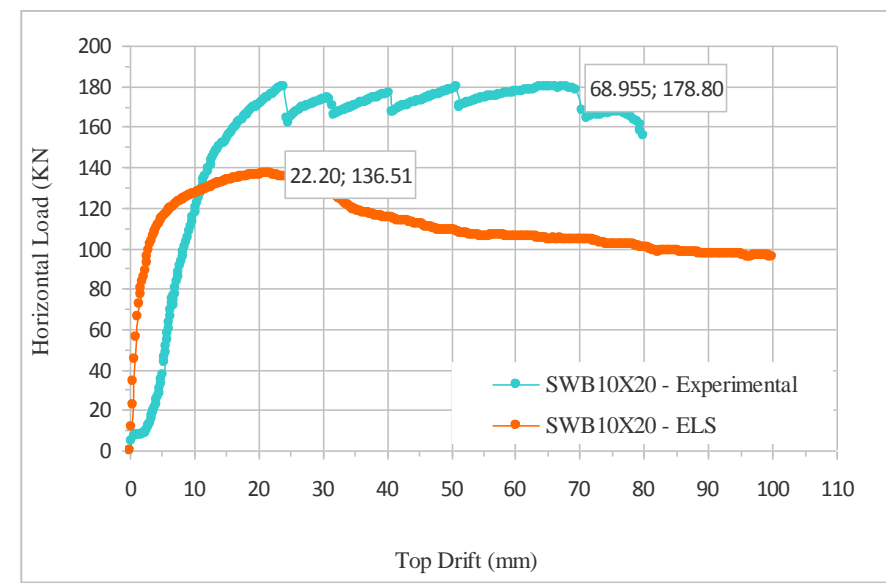

Fig. (13): Lateral Load - Top Drift Relation for SWB10X20

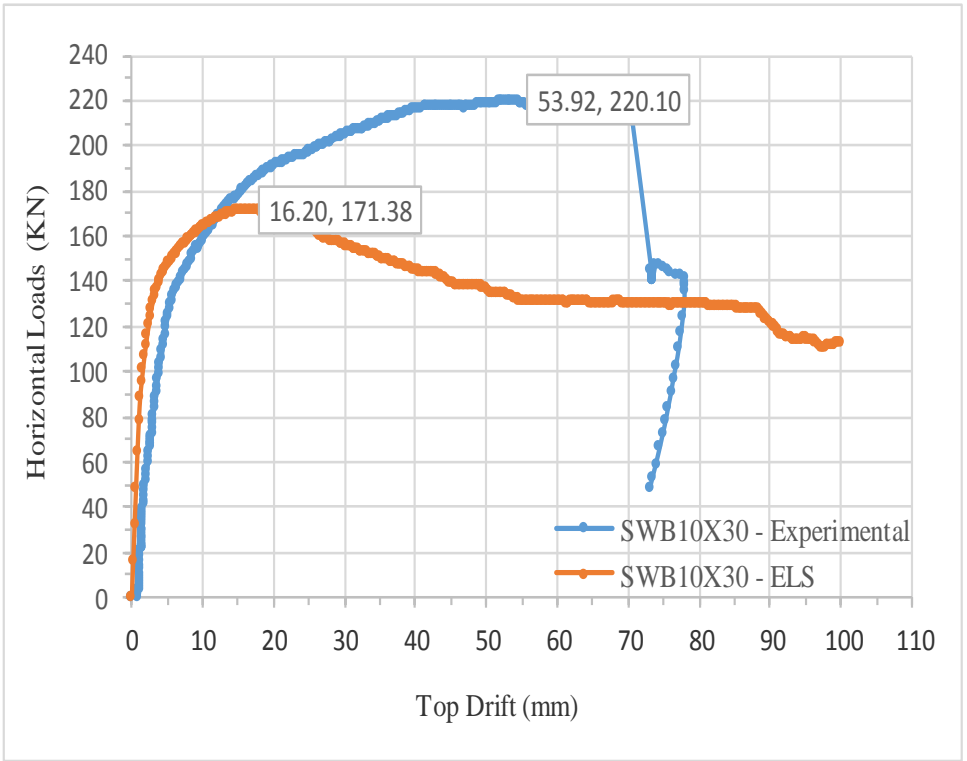

Fig. (14): Lateral Load - Top Drift Relation for SWB10X30 
AN EXPERIMENTAL INVESTIGATION OF AN INNOVATIVE COUPLING TECHNIQUE OF CONCRETE SHEAR WALLS

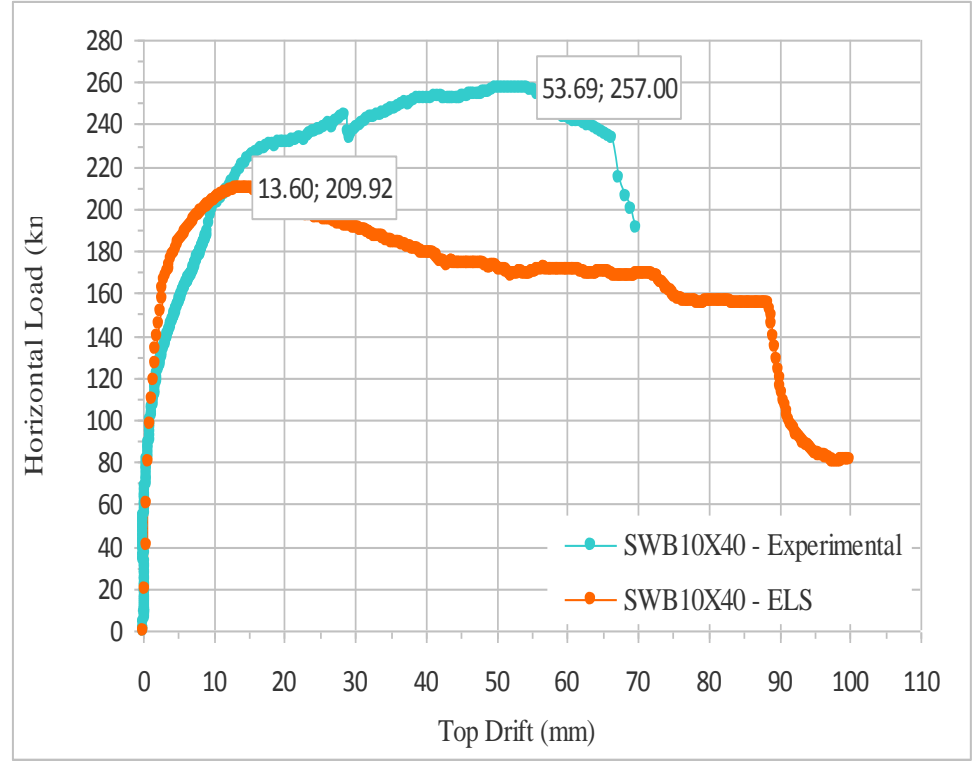

Fig. (15): Lateral Load - Top Drift Relation for SWB10X40

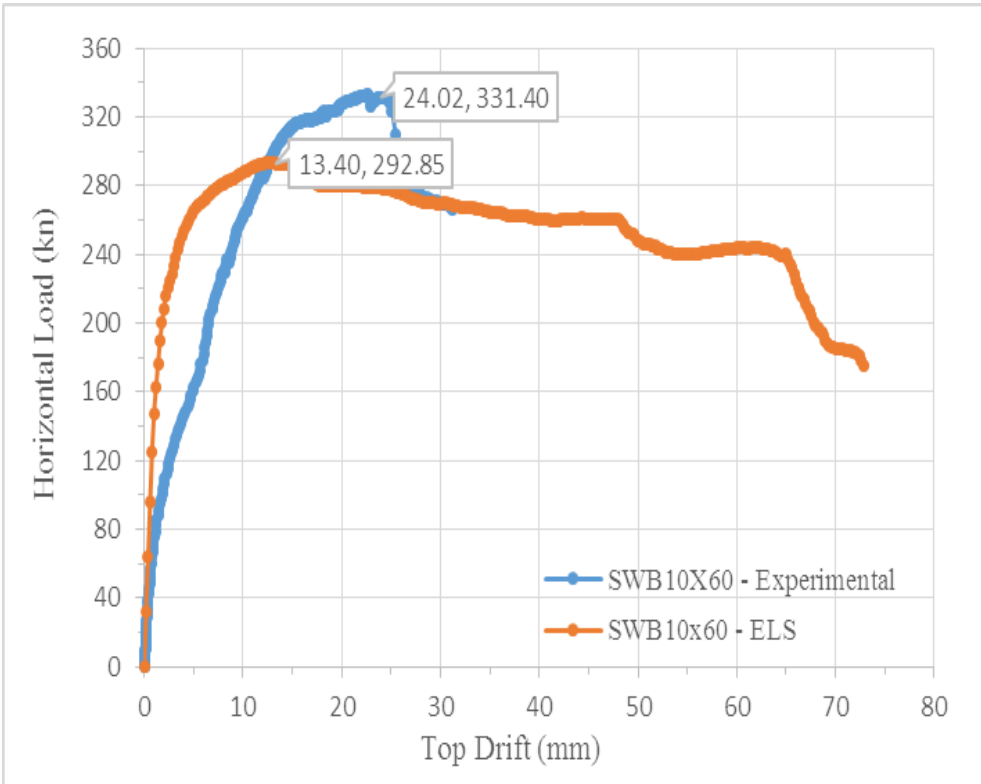

Fig. (16): Lateral Load - Top Drift Relation for SWB10X50 


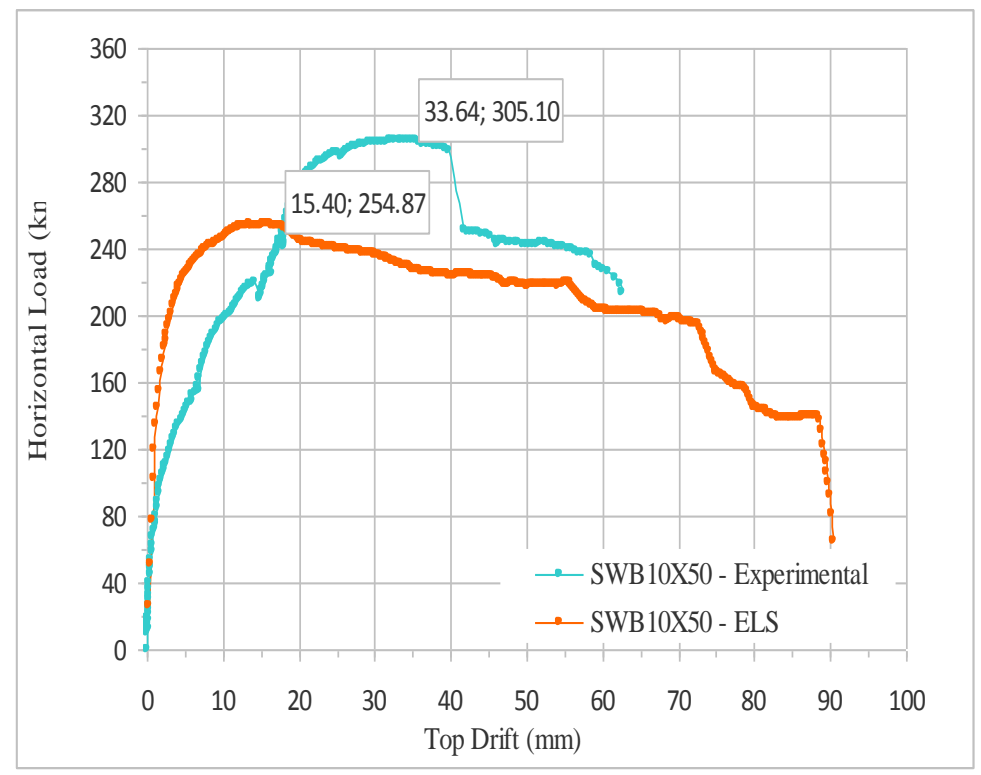

Fig. (17): Lateral Load - Top Drift Relation for SWB10X60

Table (5): Comparison between Experimental and ELS Results

\begin{tabular}{|c|c|c|c|c|c|c|}
\hline \multirow{2}{*}{ Specimen } & \multicolumn{2}{|c|}{ Experimental } & \multicolumn{2}{c|}{ ELS Software } & $\frac{\text { Pu (ELS) Pu }}{(\text { Exp. })}$ & $\frac{\Delta u(\text { ELS) }}{\Delta u(\text { Exp. })}$ \\
\hline & Pu (KN) & $\Delta u(m m)$ & Pu (KN) & $\Delta u(m m)$ & & \\
\hline SWB10X20 & 178.80 & 68.96 & 136.51 & 22.20 & 0.76 & 0.32 \\
\hline SWB10X30 & 220.40 & 53.15 & 171.38 & 16.20 & 0.77 & 0.30 \\
\hline SWB10X40 & 257.30 & 50.88 & 209.92 & 13.60 & 0.81 & 0.27 \\
\hline SWB10X50 & 305.20 & 34.10 & 254.87 & 15.40 & 0.83 & 0.45 \\
\hline SWB10X60 & 332.70 & 22.69 & 292.85 & 13.40 & 0.88 & 0.59 \\
\hline
\end{tabular}

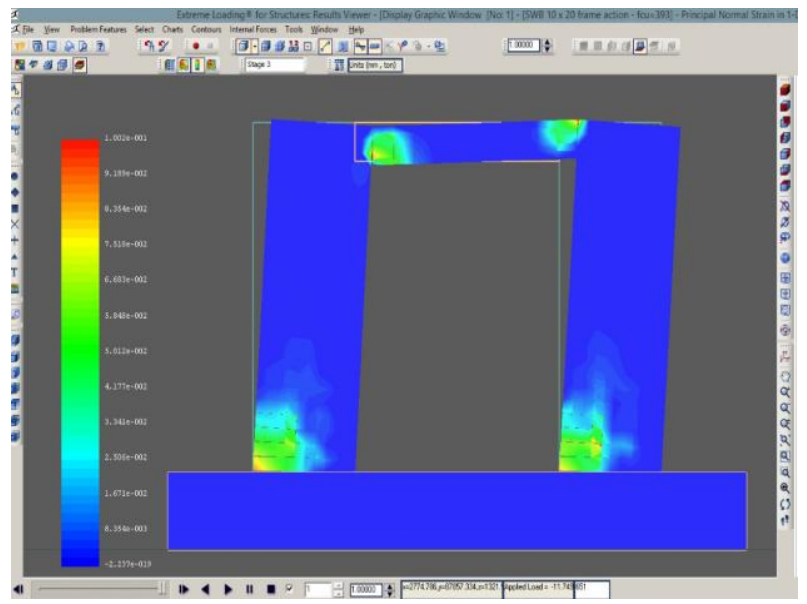

Fig. (18): Principal Strain Contours for Specimen SWB10x20 


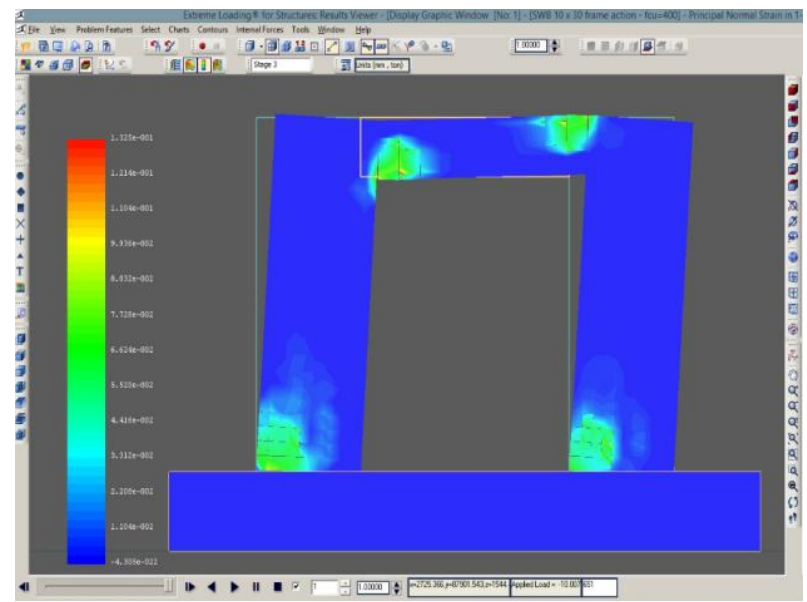

Fig. (19): Principal strain contours for specimen SWB10x30

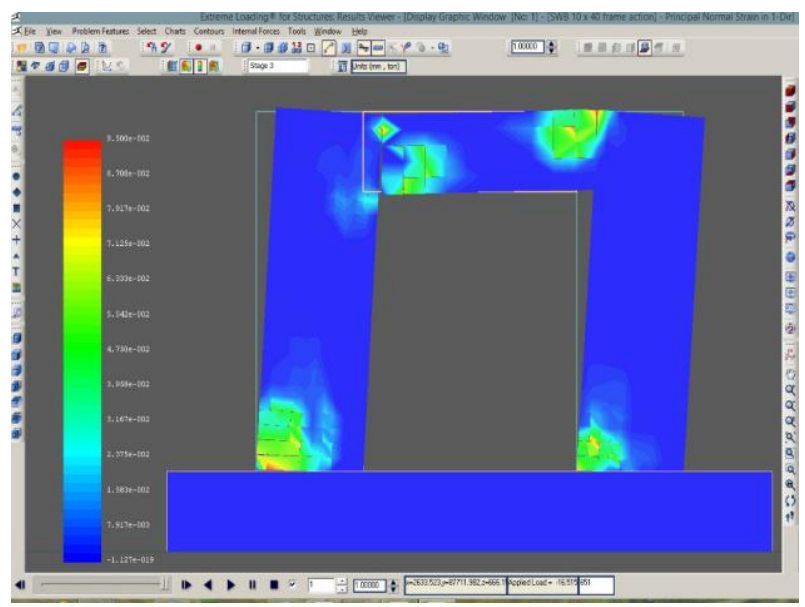

Fig. (20): Principal strain contours for specimen SWB10x40

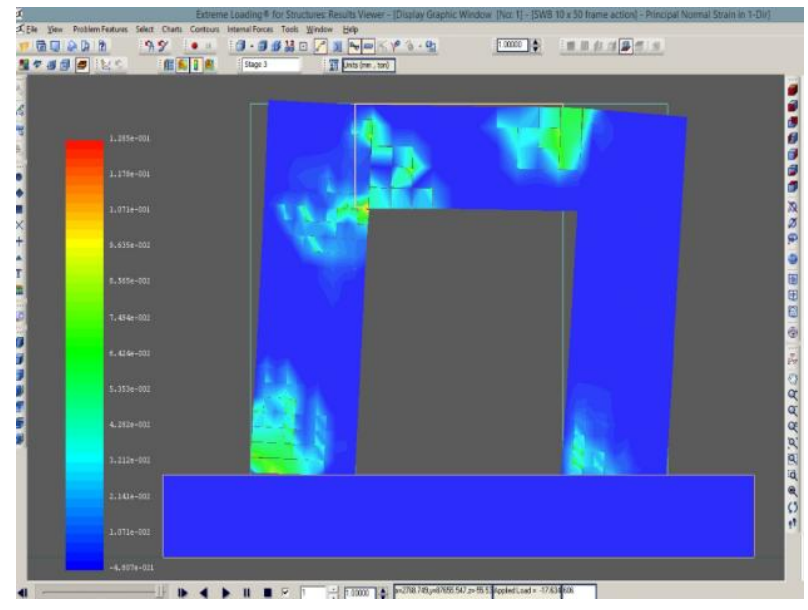

Fig. (21): Principal strain contours for specimen SWB10x50 


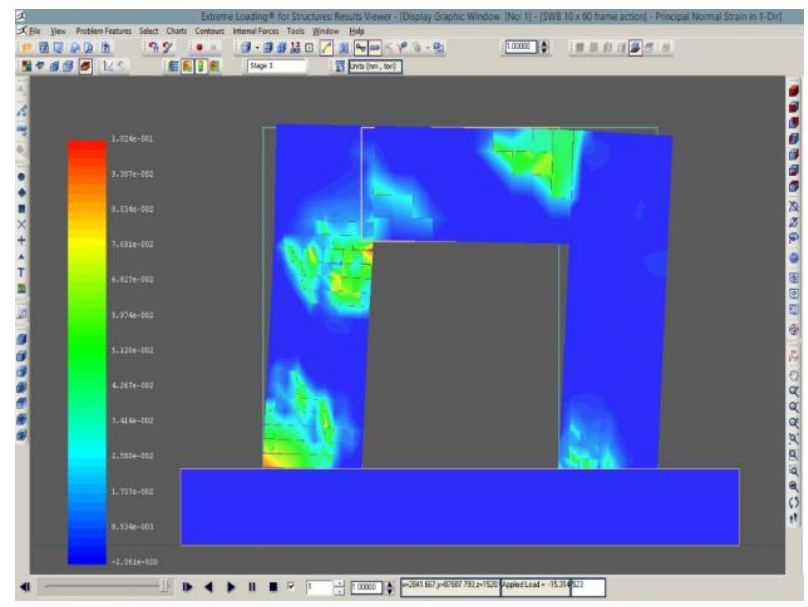

Fig. (22): Principal strain contours for specimen SWB10x60

\section{REFERENCES}

1- Fouad R.Moudarres, “Outrigger-Braced Coupled Shear Walls", (1984), ASCE Journal of Structural Engineering, Vol.110, No.12, pp.2877-2223.

2- H.C.Chan and J.S.Kuang, "Stiffened Coupled Shear Walls", April (1989), ASCE Journal of Engineering Mechanics, Vol.115, No.4, pp.689-702.

3- J.R.WU and Q.S.LI,'Structural Performance of Multi-Outrigger-Braced Tall Buildings", (2003), Structural Design of Tall and Special Buildings Journal, Vol.12, pp.155-176.

4- Z.Bayati,M.Mahdikhani and A.Rahaei, "Optimized Use of Multi-Outrigger System to stiffen Tall Buildings", (2008), 14 ${ }^{\text {th }}$ World Conference on Earthquake Engineering, October 12-17,Beijing,China.

5- Jacek Wdowicki and Elzbieta Wdowicka, "Analysis of non-planar shear wall structures with stiffening beams", (2011), CMM-Computer Methods in Mechanics, 9-12 May, Warsaw, Poland.

6- Kiran, Kamath, N.Divya, Asha U Rao, "A Study on Static and Dynamic Behavior of Outrigger Structural System for Tall Buildings", (2012), Donfrig International Journal of Industrial Engineering and Management Science, Vol.2, No.4, December.

7- Galal K, El-Sawy T. Effect of retrofit strategies on mitigating progressive collapse of steel frame structures. Journal of Constructional Steel Research; 2010; 66 (4); 520-531.

8- Sasani M, Sagiroglu S. Progressive collapse resistance of hotel San Diego. Journal of Structural Engineering; 2008; 134(3); 478-488.

9- Salem H, El-Fouly A, Tagel-Din, H. Toward an economic design of reinforced concrete structures against progressive collapse. Engineering Structures; 2011; 33:.3341-3350.

10- Park H, Suk C, Kim S. Collapse modeling of model RC structures using the applied element method. Journal of Korean Society for Roc Mechanics, Tunnel\& Underground Space; 2009; 19 (1); 43-51.

11- Helmy H, Salem H, Tageldin H. Numerical simulation of Charlotte Coliseum demolition using the applied element method. USNCCM-10 conference-Ohio-USA; 2009.

12- Sasani M. Response of a reinforced concrete infilled-frame structure to removal of two adjacent columns. Engineering Structures; 2008; 30, 2478-2491.

13- Wibowo H, Reshotkina S, Lau D. Modelling progressive collapse of RC bridges during earthquakes, CSCE Annual General Conference; 2009; GC-176-1-11.

14- Tagel-Din H, Rahman N. Extreme loading: breaks through finite element barriers. Struct Eng 2004; 5(6); 32-40.

15- Salem H. Computer-aided design of framed reinforced concrete structures subjected to flood scouring. Journal of American Science; 2011; 7(10); 191-200. 
16- D. Asprone, A. Nanni, H. Salem, and H. Tagel-Din: Applied Element Method Analysis of Porous GFRP Barrier Subjected to Blast, Advances in Structural Engineering, Vol. 13, No. 1, 153-169, 2010.

17- Helmy H., Salem H. , and Mourad S., "Progressive collapse assessment of framed reinforced concrete structures according to UFC guidelines for alternative path method", Engineering Structures 42 (2012) 127-14.

18-Helmy, H., Salem, H., and Mourad, S.,"Computer-Aided Assessment of Progressive Collapse of Reinforced Concrete Structures according to GSA Code." J. Perform. Constr. Facil., 27(5), (2013), 529-539.

19- Salem, H. and Helmy, H. "Numerical investigation of collapse of the Minnesota I-35W bridge" Engineering Structures, Volume 59, (February 2014), 635-645

20- Salem, H., Mohssen, S., Kosa, K. and Hosoda, A. "Collapse Analysis of Utatsu Ohashi Bridge Damaged by Tohuku Tsunami using Applied Element Method", Journal of Advanced Concrete Technology, Volume 12, (October 2014), 388-402

21-Ehab, M., Salem, H., Mostafa, H., and Yehia, N. "Earthquake Pounding Effect on Adjacent Reinforced Concrete Buildings" International Journal of Computer Applications, Volume 106, No.9,( November 2014), 0975 - 8887

22- Applied Science International. LLC. www.appliedscienceint.com.

23- Maekawa K, Okamura H. The deformational behavior and constitutive equation of concrete using the elsto-plastic and fracture model. Journal of the Faculty of Engineering, the University of Tokyo (B); 1983; 37 (2); 253-328.

24- Ristic,D., Yamada,Y.,and Iemura,H.(1986), "Stress-strain based modeling of hysteretic structures under earthquake induced bending and varying axial loads",Research report No. 86-ST-01, School of Civil Engineering, Kyoto University, Kyoto, Japan.

25- Tagel-Din H, Meguro K. Applied element method for simulation of nonlinear materials: theory and application for RC structures. Structural Eng./Earthquake Eng., International Journal of the Japan Society of Civil Engineers(JSCE); 2000; 17(2); 123s-148s. 